\title{
A System for Vacuum Pouring of Epoxy Tensile and Impact Specimens with a Study of the Behavior of These Specimens at $77 \mathrm{~K}$ and $293 \mathrm{~K}$
}

C. M. Fitzpatrick

W. C. T. Stoddart 


\section{DISCLAIMER}

This report was prepared as an account of work sponsored by an agency of the United States Government. Neither the United States Government nor any agency Thereof, nor any of their employees, makes any warranty, express or implied, or assumes any legal liability or responsibility for the accuracy, completeness, or usefulness of any information, apparatus, product, or process disclosed, or represents that its use would not infringe privately owned rights. Reference herein to any specific commercial product, process, or service by trade name, trademark, manufacturer, or otherwise does not necessarily constitute or imply its endorsement, recommendation, or favoring by the United States Government or any agency thereof. The views and opinions of authors expressed herein do not necessarily state or reflect those of the United States Government or any agency thereof. 


\section{DISCLAIMER}

Portions of this document may be illegible in electronic image products. Images are produced from the best available original document. 
Printed in the United States of America. Available from National Technical Intormation Service

U.S. Department of Commerce

5285 Port Royal Road, Springfield, Virginia 22161

Price: Printed Copy $\$ 4.00$; Microfiche $\$ 3.00$

This report was prepared as an account of work sponsored by an agency of the United States Government. Neither the United States Government nor any agency thereof, nor any of their employees, contractors, subcontractors, or their employees, makes any warranty, express or implied, nor assumes any legal liability or responsibility for any third party's use or the results of such use of any information, apparatus, product or process disclosed in this repuit, nur represente that its use hy such third party would not infringe privately owned rights. 
Contract No. W-7405-eng-26

FUSION ENERGY DIVISION

\begin{abstract}
A SYSTEM FOR VACUUM POURING OF EPOXY TENSILE
AND IMPACT SPECIMENS WITH A STUDY OF

THE BEHAVIOR OF THESE SPECIMENS AT $77 \mathrm{~K}$ AND $293 \mathrm{~K}$
\end{abstract}

C. M. Fitzpatrick

Fusion Energy Division

W. C. T. Stoddart

Engineering D1vision

Date Published - March 1978

NOTICE This document contains information of a preliminary nature. It is subject to revision or correction and therefore does not represent a final report.

Prepared by the OAK RIDGE NATIONAL LABORATORY Oak Ridge, Tennessee 37830 operated by UNION CARBIDE CORPORATION for the DEPARTMENT OF ENERGY
This report wos propared as an account of work This report wos propared as an account of work United States nor the United States Department of Enere ster any of their employees, ner any of of Energy, nos any of their employees. nor any of their contractors, subcontractors, or their employees, makes any warranty, express or implied, or berumos any legal liabisty or responsibuty for the accuracy, completeness or usefulness of any informsituil, apparatus, produot or
process disclosed, or represents that its use would not infringe privately owned rights. 
THIS PAGE

WAS INTENTIONALLY

LEFT BLANK 


\section{ABSTRACT}

The purpose of the investigation described in this report was to establish a suitable technique for vacuum pouring of epoxy test specimens and to study the behavior of these specimens at $77 \mathrm{~K}$ and $293 \mathrm{~K}$. A series of tensile and impact tests was conducted using specimens made from the following resins: Epon 828, Epon 871, and Epon curing agent 2 . These materials are of general interest to designers of magnets for cryogenic service. Some of the applications that may be considered are: structural support, spacing, electrical insulation, and thermal insulation. The epoxies mentioned above were selected for more extensive testing because they have heen used successfully, at room temperature in F.BT and ORMAK programs in the Fusion Energy Division at Oak Ridge National Laboratory. Liquid nitrogen was chosen over liquid helium because it is less difficult to handle, less expensive, and in most instances physical properties of epoxies seem to change very little from $77 \mathrm{~K}$ to $4.2 \mathrm{~K}$. The two main features of the vacuum pouring apparatus are (1) batches can be poured under near-identical conditions, and (2) samples can be handled free from air contamination.

Tests of the specimens were carried out at $77 \mathrm{~K}$ and $293 \mathrm{~K}$. The $77 \mathrm{~K}$ data indicate that tensile strength increases proportionally with the increase of Epon 871 relative to Epon 828. When the mixture includes more than $90 \%$ Epon 871, impact testing at $293 \mathrm{~K}$ becomes practically impossible due to the rubbery condition of the material. However, when tested at $77 \mathrm{~K}$, this same mixture evinces high tensile strength. When optimum data are sought over a wide range of temperatures, $77 \mathrm{~K}$ to $293 \mathrm{~K}$, it appears that a m1xture of $70 \%$ Epon $871,30 \%$ Epon 828 with $13 \mathrm{pph}$ of curing agent $Z$ or $50 \%$ Epon 871 , 50\% Epon 828 with 15 pph curing agent $Z$ offers the best compromise in tensile strength, modulus of elasticity, and impact resistance. 


\section{INTRODUCTION}

The purpose of the investigation described in this report was to establish a suitable technique for vacuum pouring of epoxy test specimens and to study the behavior of these specimens at $77 \mathrm{~K}$ and $293 \mathrm{~K}$. A series of tensile and impact tests was conducted using specimens made from the following resins: Epon 828, an epoxy resin with a molecular weight affording a moderate room temperature viscosity; Epon 871 , an epoxy resin especially designed for increased flexibility; and Epon curing agent $Z$, a liquid of approximately 20 poise viscosity which may be blended with liquid Epon resins at room temperature. ${ }^{2}$

\section{MIXTURES}

Five different mixtures of Epon 828, Epon 871, and curing agent $Z$ were used in tensile and impact tests. The mixtures are as follows in Table 1 .

\section{Table. 1. Resin mixtures}

$\begin{array}{crcccc}\begin{array}{c}\text { Mixture } \\ \text { identification }\end{array} & \text { Epon 828 } & \text { Epon } 871 & \text { Curing } & \text { Agent Z } \\ & & & & & \\ \text { A7135G-20 } & 100 \% & 0 \% & 20 & \mathrm{pph} \\ \text { A7135G-22 } & 75 \% & 50 \% & 17.5 & \mathrm{pph} \\ \text { A7135G-24 } & 50 \% & 70 \% & 15 & \mathrm{pph} \\ \text { A7135G-26 } & 30 \% & 100 \% & 13 & \mathrm{Pph} \\ \text { A7135G-28 } & 0 \% & & 10 & \mathrm{pph}\end{array}$

\section{SPECIMEN PREPARATION}

Appropriate amounts of each epoxy and curing agent $Z$ were weighed in separate containers. The individual containers were placed in a desiccator, outgassed until entrapped air was pumped out (down to 300-500 torr), and then brought up to atmospheric pressure using nitrogen gas. The components were then poured very slowly down the side of a single container so as to avoid entrapping air. For the same reason, the container was stirred with round rather than overlapping movements. The resulting mixture was then poured into vacuum pouring 
funnels (see Item A, Fig. 1) and outgassed until bubbling stopped or became very slow, down to 300-400 torr. The specimen molds were prepared by cleaning with a degreaser, drying, and then coating them with a very thin layer of mold release (Ram Chemical 225). The molds were then preheated to about $125^{\circ} \mathrm{F}$ in order to minimize shrinkage and surface blemishes on the specimen. This process also seems to minimize the seam marks which occur when a split mold is used. The molds were placed in desiccators directly beneath the vacuum pouring funnels and pumped down to approximately 500 torr (see Item B, F1g. 1). The pressure in the vacuum pouring funnel was slowly raised to nonr atmospheric pressure by releasing nitrogen gas into the funnel (see Item C, Fig. 1). An arrangement of a ground glass valve, a gum rubber hose, and a copper tube (see Item D, Fig. 1.) was employed for pouring the mixture from vacuum funnel to mold. The pouring was facilitated (see Item E, Fig. 1) by using an angle in the pouring tubes, a pouring trough screwed onto the top of the mold, and a lever clamped to the pouring tube to maneuver the tube into the proper position. After the pouring, the samples were outgassed in the desiccator for a short time, then removed from the desiccator by valving in nitrogen gas lu bring the pressure slowly up to atmospheric pressure. The molds were then placed in an over to cure at $150^{\circ} \mathrm{F}$ for 24 hours. The specimens were removed from the molds and checked with a polariecupe rur residual stresses. If signs of stress were found, specimens wcre annealed by slowly raising the temperature to slightly above $150^{\circ} \mathrm{F}$ and then cooling very slowly at an approximate rate of $5^{\circ} \mathrm{F} / \mathrm{hr}$ until room temperature was reached. With a fine emery cloth, specimens were smoothed after annealing. Burnishing tools were used to eliminate seam marks or any other blemishes that might cause premature failure during testing.

\section{TESTING}

Nine tensile specimens were poured from each mixture. The specimens were round, with a diameter of 0.250 in., and a gage length of 1.125 in. Five of the specimens were tested at $293 \mathrm{~K}$ and four were tested at $77 \mathrm{~K}$ (see Figs. 2 and 3 ). The tensile tests were carried out using a motor- 
driven Houndsfield Tensometer ${ }^{3}$ with seven spring beams giving ranges with maximum loads of 2 tons, ${ }^{4} 1$ ton, $10001 \mathrm{~b}, 5001 \mathrm{~b}, 1251 \mathrm{~b}$, and 62.5 1b. Tensile strength vs epoxy mixture data may be noted in Fig. 2 (refer to Table 1 for amount of curing agent $z$ ). Modulus of elasticity vs epoxy mixture may be noted in Fig. 3 .

Forty impact specimens were poured from each mixture at the same time and under the same conditions as the tensile specimens were poured. The impact specimens were $1 / 4$ in. square and $1-1 / 2$ in. 1 ong, notched to a root diameter of $0.144 \mathrm{in}$. Twenty of the specimens were tested at $77 \mathrm{~K}$ and 20 were tested at $293 \mathrm{~K}$. The impact tests were carried out using a Houndsfield Plastic Testing Machine. ${ }^{3}$ This machine is designed to measure the work done in breaking a notched test piece, which indicates the resistance a material can offer to stress concentration. In the impact test, the energy of fracture is equal to the difference in the energy stored in the tup before and after fracture. (See Fig. 4 for Houndsfield Plastic Impact Testing Machine.) If $\mathrm{E}=$ energy stored in the tup, I.S. = impact strength of the test piece, and $e=$ residual energy, then I.S. = E $-\varepsilon$. The stored energy is shown in numbers stamped on the tups and varies from $2 \mathrm{ft}-1 \mathrm{~b}$ down to $1 / 32 \mathrm{ft}-1 \mathrm{~b}$. The residual energy is indicated by the height the tup ascends after breaking the test piece; for a given value of $e$ to be subtracted each time, the dial is graduated backwards and gives a direct reading of the fracture of I.S. In each test, the dial reading must be multiplied by the figure stamped on the tup. (Tables are furnished with the equipment to enable the true energy of the fracture to be obtained without calculation.)

The impact test in liquid nitrogen was carried out in the following manner. The specimen was placed in a dewar of liquid nitrogen and allowed to reach ambient temperature. It was then removed from the liquid nitrogen and placed on the impact testing machine, and the tup was released. After considerable practice, the entire test of transfer of one specimen from dewar to impact tester and release of tup required from 5 to 10 seconds. The wide variation of impact data at room temperature may be attributed to the difficulty in developing a propagating fracture in a highly flexible medium. This effect is greatly reduced at cryogenic temperature due to the increase th stiffness. 
5. CONCLUSIONS

Five different batches of epoxy mixture (see Table 1), each weighing 500 grams and prepared under nearly identical conditions, were tested. The identification, mixture, and test results of each batch may be deduced by the study of Figs. 2, 3, and 4 (refer to Table 1 for amount of curing agent $Z$ in each batch). It is at once evident from the $77 \mathrm{~K}$ tests that tensile strength increases proportionally with the amount of Epon 871 in the mixture (see Fig. 5). When the mixtures are more than 90\% Epon 871, 1mpact testing at $273 \mathrm{~K}$ becomes practically impossible due to the rubbery condition of the materlal; when tested at $77 \mathrm{~K}$, such a mixture evinces high tensile strength. It appears that $70 \%$ Epon 871 , $30 \%$ Epon 828 with 13 pph curing agent $\mathrm{Z}$, or possibly $50 \%$ Epon $871,50 \%$ Epon 828 with $15 \mathrm{pph}$ curing agent $\mathrm{Z}$, offers the best compromise in tensile strength, modulus of elasticity, and impact resistance when optimum data are being sought over a wide range of temperatures. However, 100\% Epon 871 with $10 \mathrm{pph}$ curing agent $Z$ is found to be stronger than any other batch when tested for tensile strength alone at $77 \mathrm{~K}$. If one considers impact resistance only (tested at $273 \mathrm{~K}$ ), then $70 \%$ Epon 871 , 30\% Epon 828 with $13 \mathrm{pph}$ curing agent $\mathrm{Z}$ is found to have the highest shock resistance.

Some other materials were selected for testing in this series that were thoughil to be useful as potting compounds or as fabricated insulation separators. Some of these materials were available in a directly usable form, which could be purchased, while others had to be produced on sight due to the parameters which were to be investigated. The measured ultimate strengths of these materials are reported in Table 2. All of the materials in this table were fabricated from hulk stock. Stycast $2850 \mathrm{FT}$ was the only material mentioned in thu Lable that had to be mixed, and it was of such high viscosity that it was not vacuum poured, but outgassed in the molds after it was poured. The specimens did not show any signs of voids. 
Table 2. Ultimate tensile strength of bulk materials

Ultimate Tensile Strength

\begin{tabular}{|c|c|c|c|c|}
\hline & \multicolumn{2}{|c|}{$293 \mathrm{~K}$} & \multicolumn{2}{|c|}{$77 \mathrm{~K}$} \\
\hline Stycast $2850 \mathrm{FT}$ & 14 & $(2,000)$ & 105 & $(15,000)$ \\
\hline$G-30$ & 340 & $(50,000)$ & 105 & $(15,000)$ \\
\hline$G-50$ & 310 & $(45,000)$ & 550 & $(80,000)$ \\
\hline DuPont 101 & 48 & $(7,000)$ & 130 & $(18,500)$ \\
\hline Delrin & 69 & $(10,000)$ & 140 & $(21,000)$ \\
\hline Vespe1 211 & 62 & $(9,000)$ & 100 & $(14,500)$ \\
\hline Vespel $92 Y 77$ & 86 & $(12,500)$ & 105 & $(15,000)$ \\
\hline Tefzel. & 32 & $(4,700)$ & 83 & $(12,000)$ \\
\hline Insulation Papers & 19 & $(2,800)$ & 45 & $(6,500)$ \\
\hline
\end{tabular}

Some experiments have recently been performed to test the $70 \% 871$, $30 \% 828,13 \mathrm{pph}$ curing agent $\mathrm{Z}$ with the addition of $0.5 \%$ Silane 6020 and 6040, two coupling agents manufactured by the Dow Corning Corporation. The few tests performed with these agents have shown favorable results and seem to warrant further investigation.

\section{REFERENCES}

1. Tradenames of materials are used in this report for clarity. In no case does such selection imply recommendations or endorsement by the authors, nor does it imply that the material is necessarily the best available for the purpose.

2. Epon resins are manufactured by the Plastic and Resin Division of Shel1 Chemical Company.

3. Houndsfield Tensometer manufactured by Tensometer Limited, 81 Moorland Road, Croydon, Surrey, England.

4. British ton (2240 lbs). 


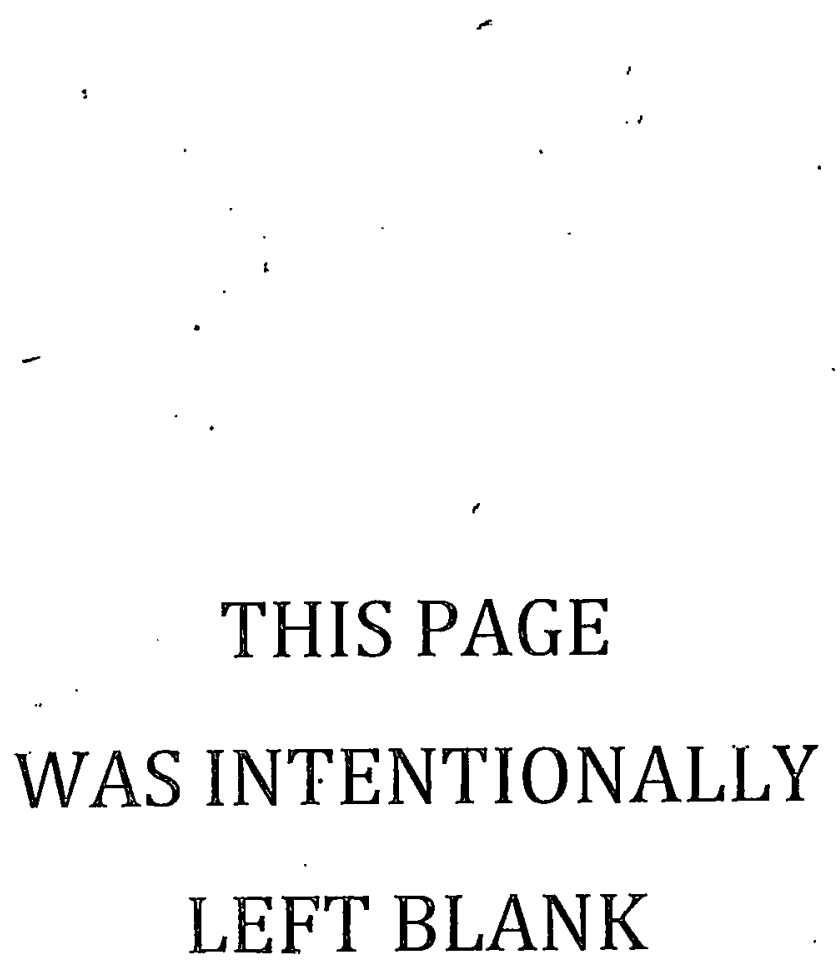


ORNL/TM-5493

\section{INTERNAL DISTRIBUTION}

1. J. K. Ballou

2. L. A. Berry

3. R. L. Brown

4. P. B. Burn

5. W. D. Cain

6. W. A. Fietz

7-16. C. M. Fitzpatrick

17. W. H. Gray

18. P. N. Haubenreich

19. W. R. Hendrich

20. R. F. Hibbs

21. C. J. Long

- 22. M. S. Lubell

23. J. W. Lue

24. J. N. Luton

25. J. A. Mayha11

26. J. R. Miller
27. 0. B. Morgan

28. H. Postma

29. M. W. Rosenthal

30. J. L. Scott

31. T. E. Shannon

32. D. Steiner

33. W. C. Stoddart

34. P. B. Thompson

35. P. L. Walstrom

36-37. Central Research Library

38. Document Reference Section

39-40. Laboratory Records Department

41. Laboratory Record's - ORNL-RC

42-43. Fusion Energy Division Library

44. Fusion Energy Division

Communications Group

\section{EXTERNAL DISTRIBUTION}

45. E. Adam, Airco, 100 Mountain Avenue, Murray Hill, NJ 07974

46. R. W. Boom, 513 Engineering Research Building, University of Wisconsin, Madison, WI 53706

47. J. L. Christian, General Dynamics/Convair Division, San Diego, CA 92112

48. D. L. Coffey, American Magnetics Inc., P.O. Box R, Oak Ridge, TN 37830

49. D. N. Cornish, Lawrence Livermore Laboratory, P.0. Box 808, Livermore, CA 94550

50. R. W. Derby, Department of Energy, Mail Stop G-234, Washington, D. 2.0545

51. Director, Research and Technical Support Division, Depaltiünt of Energy, Oak Ridge Operations, Oak Ridge, TN 37830

52. F. R. Fickett, National Bureau of Standards, Boulder, CO 80302

53. H. K. Forsen, Exxon Nuclear Co., Inc., 777 106 th Avenue, NE, C-00777, Bellevue, WA 98009

54. H. P. Furth, Princeton Plasma Physics Laboratory, P.0. Box 451, Princeton, NJ 08540

55. R. W. Gould, Department of Applied Physics, California Institute of Technology, Pasadena, CA 91109

56. C. K. Jones, Manager, Cryogenic Research Laboratory, Westinghouse Electric Corporation, R\&D Center, Pittsburgh, PA 15235

57. D. B. Montgomery, MIT, National Magnet Laboratory, 170 Albany Street, Cambridge, MA 02139

58. D. J. Rose, Department of Nuclear Engineering, Massachusetts Institute of Technology, Cambridge, MA 02139 
59. C. H. Rosner, Intermagnetics General Corporation, Charles Industrial Park, New Karner Road, Cuilderland, NY 12084

60. Z. J. J. Stekly, Magnetic Corporation of America, 179 Bear Hill Road, Waltham, MA 02154

61. C. von Keszycki, Grumman Aerospace Corporation, Research Center, Building 26, Bethpage, NY 11714

62. J. Wong, Supercon, Inc., 9 Erie Drive, Natick, MA 01760

63. H. H. Woodson, Chairman, Department of Electrical Engineering, University of Texas, Austin, TX .78712

64. E. J. Ziurys, Division of Magnetic Fusion Energy, Department of Energy, Mail Stop G-234, Washington, DC 20545

65-91. TIC, P.0. Box 62, Oak Ridge, TN 37830 